\title{
Editors' Introduction
}

Wilfrid Mellers has been associated with Popular Music since its beginnings. Before that, on the wider scholarly stage, he was a pioneer in the academic study of popular music - particularly within the musicological community - and his importance is enormous, both for a specific body of work and for his charismatic example: after Mellers, it became permissible (for better or worse!) for professors of music to talk about the Beatles. It's a pleasure for us, in the year of his eightieth birthday, to salute his contribution and to thank him for it.

Not that Wilfrid set out to become a 'professor of pop'. Indeed, an important mark of his work has been a refusal to follow orthodox divisions of the musical field, an insistence that the same perspectives can be applied to any music, and a willingness to identify musical interest and value anywhere. This is one reason why he could become an inspiration to young students even before he had written a word on popular music. In the early sixties, as a Cambridge undergraduate rapidly growing disillusioned with existing musicology, I discovered in his contribution to Man and His Music (a general history of art music in the West) a perspective which transformed my outlook. Music, it transpired, wasn't just a matter of technical procedures and formal analysis; it could tell us abut people, people in particular historical contexts, and connect us with their experience; it contained social meaning. My story wasn't unique. Many others started to connect 'music' and 'society' as a result of reading Mellers, among them several popular-musicscholars-to-be (Philip Tagg, for example, was going through a similar experience to mine, in the same Cambridge, at the same time). So it seems appropriate that the first piece in this volume, by John Shepherd, should stand consciously in a 'music and society' tradition to which Wilfrid made such a formative contribution.

Man and His Music was written in the fifties. By the beginning of the next decade, a longstanding interest in American music was taking Mellers to the USA for two years, a stay which resulted in the 1964 book Music in a New Found Land. Here for the first time popular musics (blues, jazz, musicals) are discussed at length alongside concert music (though actually Offenbach, Johann Strauss and Gershwin appear briefly in the earlier book). Over the next few years, as the Select Bibliography printed later in this issue shows, articles and reviews on a wide variety of topics in popular music were appearing; and at the same time Wilfrid was developing the music department he had founded at the new University of York, where popular music figured as part of an innovative curriculum. The American music chapter of Caliban Reborn (1968) features not only jazz but also sixties pop, including the Beatles and Bob Dylan, and this interest led in due course to complete books (Twilight of the Gods (1973) on the Beatles; A Darker Shade of Pale (1984) on Dylan). Wilfrid's output in more recent years has continued to include publications on popular music, most notably his book on women singers, Angels of the Night (1986). The American dimension of his work is well reflected in the articles assembled in this issue, notably in the pieces by Hamm, Peretti, Horn and 
Keil; recent pop is less well represented, though the sixties are there by implication in Dave Laing's piece, and John Potter discusses some recent female musicians.

It seems fair to say that in many ways the Mellers popular music oeuvre bulks larger in reputation than in influence. Perhaps this is often the way with pioneers unwilling to bend with subsequent intellectual trends. In the Mellers case one of the keys to this history is to be found in his debt to the literary critic F. R. Leavis, whose influence in Britain reached a peak in the 1950s and has now plummeted almost to zero. This parabola is itself symptomatic of deeper changes in the intellectual and social topography of British culture. Dave Laing pursues the wider influence of Leavisism on popular music studies, in his article. One quality Mellers found in Leavis which must have fed into his 'social hermeneutic' perspective was the conviction that forms of art are integrally connected with the modes of social life within which they existed - that together these made up, as Raymond Williams was later to put it, a 'whole way of life'. The sociality of music is so taken for granted by popular music scholars that we rarely stop to remember those whose work gave us the tools to think about it. A second Leavisite quality taken over into Mellers is the emphasis on close reading of texts, and here we find that this has permeated subsequent popular music research much more hesitantly - and with variable results. It's fair to say, too, that Mellers' own method hasn't been particularly influential, in fact it has been the object of criticism for its 'subjectivism'. It might be as well to postpone leaping too decisively onto this bandwagon, however, until we have produced a coherent alternative of at least equal powerand one that solves the problem of the responding subject (rather than writing agency out of the story altogether). Which brings us to the third important quality in the Leavis inheritance, namely the insistence on the moral dimension of art. The idea that the value of music (as of literature) is completely bound up with the quality of the human experience and human relationships somehow distilled there has percolated the world of popular music scholarship in a very tangled way, but we can say that it's now virtually dead. Tarred with the sinful brush of the 'authenticity myth', it was quite early transmuted into evaluations of political tendency, and then, entering the value-free zone of so-called postmodernism, was laughed out of court altogether. Its story parallels the rise and decline of 'rockism' in the music. So that, when Pete Townshend talks about 'the idea that rock and roll recognised the value of the open-ended dream that if our hearts are true or whatever, we will see our vision' (Guardian, 12 June 1993), one can imagine Wilfrid Mellers nodding in sympathy, but most popular music scholars and critics today would turn away in embarrassment, whether guilty, contemptuous or uncomprehending. And yet some may feel (just aging 'rockists' and 'folkies'?) that the future of music as a progressive social force depends on people's ability to re-articulate some vision of its status in our moral life. Charles Taylor's book The Ethics of Authenticity (1991) suggests one way in which the myth of authenticity may be rehabilitated, and Paul Gilroy's recent The Black Atlantic (1993) refuses to give up the ethical status of black music; there are other possible strategies too, and so it's interesting that, just as several articles here are unexpectedly positive about the Mellers hermeneutic technique, at least one (Dave Laing's) tries to open the possibility of re-thinking the inheritance of Leavis's moral view of culture. If this collection of articles were to encourage any re-assessment of Wilfrid Mellers' popular music work, then, I myself hope that it will lead to new ideas in these two intertwined areas: methods of textual interpretation, and philosophy of aesthetic/moral valuation. 
In truth, though, this collection has been put together with no such programmatic intention in the front of our minds, nor, certainly, with any idea of providing a comprehensive assessment of the Mellers oeuvre. Rather, we have wanted to offer a range of articles covering aspects of some of the topics (by no means all) on which Wilfrid himself has written, as a tribute to his role in opening them up for further research. We hope he enjoys them.

Richard Middleton 